\title{
Complete mouth rehabilitation with zirconia fixed partial dentures supported by natural teeth and implants: A case report
}

\author{
Jeong-Hye An, Ji-Hye Jung, Hye-Won Cho*
}

Department of Prosthodontics, Wonkwang University College of Dentistry, Iksan, Korea

\begin{abstract}
When a maxillary implant-supported fixed prosthesis is planned for anterior partially edentulous region, the degree of atrophy of the residual ridge, prospective location of the implants and inclination of the implant axis, soft tissue volume dimensions, esthetics, and phonetics of the patient should be considered. The signs of osteoarthritis and deviation in form on the left condyle head were found in the temporomandibular joint radiogram of the patient reported herein due to her habit of unilateral chewing for 20 years. Furthermore, the patient had loss of left mandibular posterior teeth, an unequal occlusal plane, extruded and rotated mandibular anterior teeth, a high smile line, and high expectations. This report describes the treatment procedure for establishing occlusal plane, physiologic occlusion with stabilized posterior tooth contact and anterior guidance, and equilibration in centric relation-maximum intercuspation discrepancy using zirconia restorations with a computer-aided design/computer-aided manufacturing system in an adapted centric posture.
\end{abstract}

Key Words: CAD-CAM, Crown, Prosthesis, Zirconia

(c) This is an open-access article distributed under the terms of the Creative Commons Attribution Non-Commercial License (http://creativecommons.org/licenses/by-nc/4.0) which permits unrestricted noncommercial use, distribution, and reproduction in any medium, provided the original work is properly cited.

\section{서 론}

다수 치아가 상실된 부분무치악 환자는 임플란트를 이용해 수복하는 경우 잔존치아의 손상을 막고, 이차우식이나 치수염, 치주염의 발생을 감소시키며 성공적인 수복이 가능해진다[1]. 그러나 상악 전치부 수복에 있어서는 치조제의 골흡수 정도, 임 플란트의 위치와 경사, 연조직의 양과 질, 미소선과 치관의 노출 정도, 발음과 심미성 등에 대해 신중한 고려가 필요하다[2-4].

자연치와 임플란트를 이용한 완전구강회복의 경우 중심위 (centric relation)를 이용한 교합 형성이 선호되고 있다[5,6]. 그러나 오랫동안 편측 저작을 하여 과두변화가 발생한 경우에 도 안정화된 습관성 폐구위를 가진 환자에서는 적응된 중심위 (adapted centric posture)와 조화되는 최대교두감합위를 형성 하는 것이 추천되고 있다[7]. 비록 악관절 구조는 변형되었지만 불편함 없이 부하를 받아들일 수 있으며 교합과 악관절 간 조화 가 이루어질 수 있도록 주의가 필요하다.

고정성 임플란트 지지 보철물의 치료 계획은 임플란트의 수 와 수복재에 대한 다양한 선택이 가능하다[3,4]. 최근 computer-aided design/computer-aided manufacturing (CAD$\mathrm{CAM}$ ) 시스템이 보철 영역에 등장하면서 어떠한 보철물을 어떤 방식으로 제작하는 것이 가장 보철물의 수명과 심미성에 유리 한지에 대한 의견이 분분하다. 비록 구강 스캐너의 정확도가 높 아지고 있지만, 임플란트를 포함하는 전악 인상의 경우 구강 스 캐너보다 기존 인상법으로 모형을 제작하고 이를 기공용 스캐

Received August 7, 2019; Revised September 4, 2019; Accepted September 5, 2019

Corresponding author: Hye-Won Cho, Department of Prosthodontics, Wonkwang University College of Dentistry, 460 Iksan-daero, Iksan 54538 , Korea.

Tel: +82-63-859-2938, Fax: +82-63-857-4002, E-mail: hwcho@wku.ac.kr

Copyright $\odot$ 2019, Oral Biology Research Institute 
너로 디지털 인상을 채득하는 것이 보다 정확성이 높다[7,8]. 또 한 구치부에서도 단일 구조 지르코니아관의 파절률이 낮고 수 명이 길어지면서 그 사용이 늘어나고 있다[3].

본 증례는 상악 구치부에 자연치가 남아있고, 전치부 무치악 부위는 임플란트로 수복하고자 할 때, 편측 저작으로 인한 과두 형태 변화가 있는 환자에서 지르코니아를 이용한 전악 구강회 복을 시행하기 위한 치료 계획과 치료 과정을 보철기공 과정과 함께 서술하고자 하였다.

\section{증례보고}

\section{진단과 준비}

본 증례의 환자는 37세 여성으로 어릴 때 사고로 인해 좌측 하악 구치를 상실하였으며 좌측 저작이 힘들다는 주소로 내원 하였다. 특기할 전신병력은 없었으며 18년 전 교통사고로 상악 전치부 및 제 1 소구치를 상실하여 양측 제 2 소구치, 제 1 대구치, 제2대구치 $(\# 15,16,17,25,26,27)$ 를 지대치로 하는 전악 고정 성 보철물이 장착되어 있었으며 이 중 \#25는 우식으로 인해 치 관이 분리된 상태였다. 하악에는 좌측 제 1 소구치에서 제 2 대구 치에 이르는 부분무치악 부위가 존재하였다(Fig. 1A).

구내에서는 좌우 교합평면의 부조화 및 하악 전치의 정출이 관찰되었으며 방사선 사진상 좌측 과두의 편평화 및 골관절염 소견이 관찰되었다(Fig. 1B, C). 본 환자는 2007년 원광대학교 치과대학 부속병원에서 턱관절 방사선 사진 및 파노라마 방사 선 사진상 정상인 우측 과두에 비해 좌측 과두의 편평화와 형태 이상으로 골관절염이 의심된다는 진단을 받은 바 있다. 2017년 재내원 시 원광대학교 치과대학 부속병원 구강내과와 협진 결 과 간헐적 관절음과 최대 개구 시 좌측 관절의 불편감 이외에는 저작에 큰 문제가 없어 적응된 중심위를 그대로 유지하도록 권 고되었다.
상악 잔존치아 중 기존 보철물의 제거 후 이차우식과 치주염, 교합평면에 장애가 되는 치아를 선별하여 발거하기로 결정하였 다. 발거할 치아로는 상악 우측 제 3 대구치, 제 2 대구치, 좌측 제 2 소구치, 제 3 대구치, 하악 좌측 제 3 대구치, 우측 제 2 소구치, 제 1 대구치 및 제 2 대구치 $(\# 18,17,25,28,38,45,46,47)$ 가 선정 되었고, 상악 좌측 제 1 대구치와 제 2 대구치는 재근관치료를 시 행하였다. 무치악 부위는 임플란트와 자연치를 이용, 단일 구조 지르코니아 고정성 보철물로 수복하기로 계획하였다.

\section{치료 계획 수립과 임플란트 매식체 식립}

기존 보철물 제거 후 발거하기로 한 치아는 모두 8 개였으며, 환자의 불편감을 최소화하고 적응된 중심위를 유지하기 위해, 하악 우측 구치부 잔존치아는 좌측 구치부의 교합이 형성될 때 까지 보존하였다. 하악 좌측 구치부에 먼저 3개의 임플란트(US II; Osstem, Seoul, Korea)를 \#34, 36, 37 위치에 골이식을 동반 한 2회법으로 매식하였다.

상악 전치부는 기존 보철물을 복제해 제작한 방사선 촬영 용 스텐트를 이용하여 콘빔형 전산화 단층 촬영(cone beam computed tomography; Alphard Vega 3030; Asahi, Kyoto, Japan)을 시행하고 골량과 골질을 분석하였다. 상악 전치부에 는 \#11, 13, 14, 21, 23, 25 위치에 임플란트 식립을 계획하였 으며, 먼저 자가골 및 인공골(Bio-Oss; Geistlich, Wolhusen, Switzerland)을 사용한 수평적 골이식을 시행하고 차폐막(Ossix Plus; Datum dental Ltd., Lod, Israel)을 덮고 봉합하였다. 5 개월 후에 추가적 골이식과 함께 6개의 임플란트(TS III; Osstem)를 식립하고 3주 후 임시의치를 장착하였다. 이 기간 동안 좌우 교합평면을 조화시키기 위해 불완전한 근관치료 상태인 상악 좌측 제1대구치와 제2대구치를 재근관 치료하고 임시 수 복물을 장착하였다(Fig. 2).
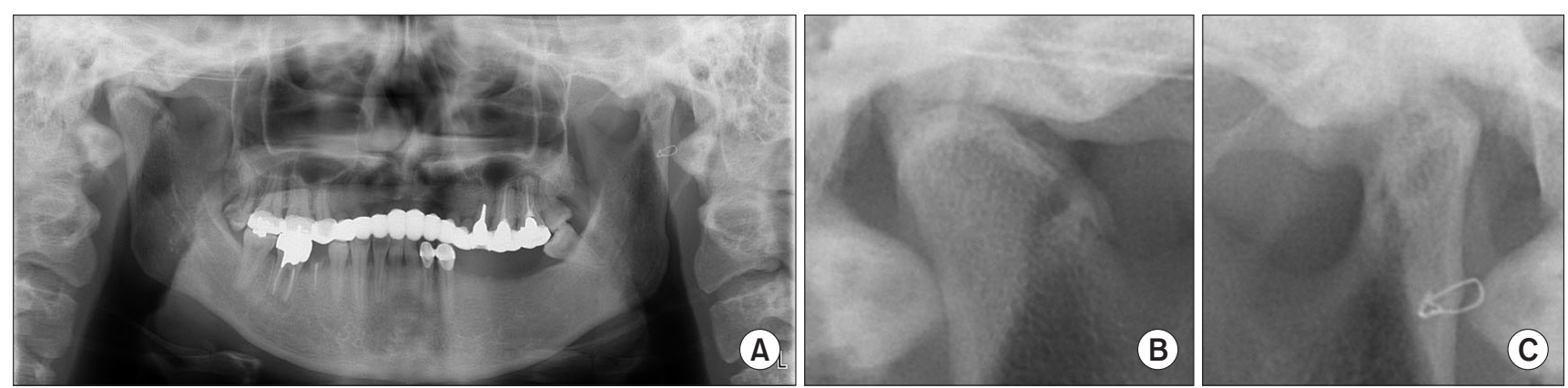

Fig. 1. Pretreatment radiologic view. (A) Panoramic view. (B) Right condyle on temporomandibular joint (TMJ) radiograph. (C) Left condyle on TMJ radiograph. Deviation in form was found on left condylar head. 

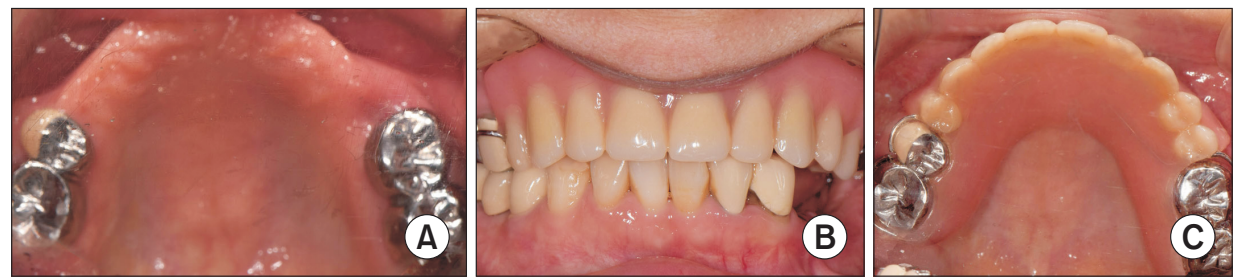

Fig. 2. Pretreatment clinical intraoral view. (A) Partial edentulous area of maxillary anterior region. (B) Frontal view of removable interim prosthesis. (C) Occlusal view.
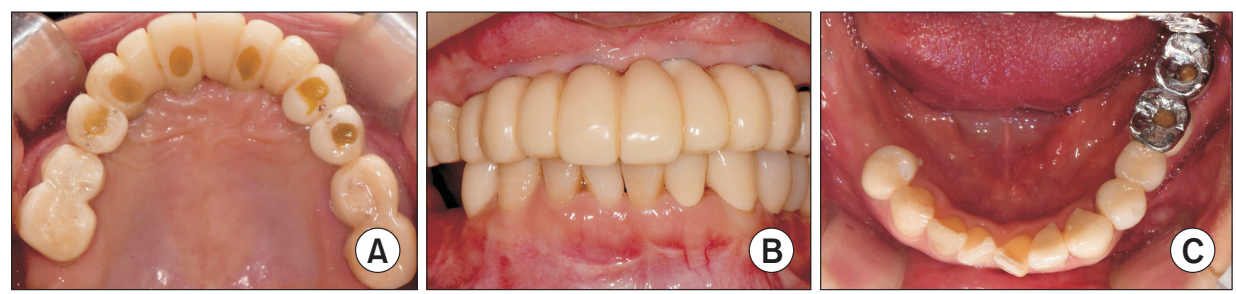

Fig. 3. Initial provisional implantsupported fixed prosthesis. (A) Maxillary occlusal view. (B) Frontal view. (C) Mandibular occlusal view.
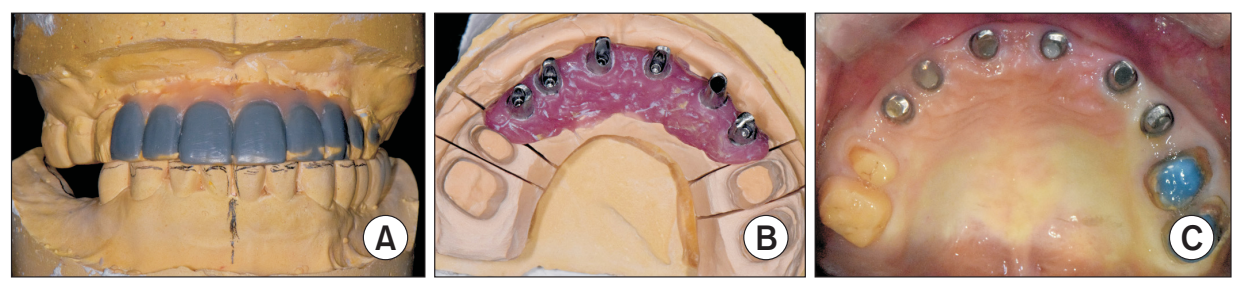

Fig. 4. Custom abutments were made regarding provisional restoration. (A) Diagnostic wax-up. (B) Custom abutments are made. (C) Custom abutments are placed.

\section{임시 보철물의 장착}

3개월 후 이차수술을 시행하고, 알지네이트(Aroma fine; GC Corp., Tokyo, Japan)로 예비인상을 채득하여 개인 트레 이(Ostron 100; GC Corp.)를 제작하였다. 매식체에 pick-up type의 인상용 코핑을 체결해 자가중합 레진(Pattern resin LS; $\mathrm{GC}$ Corp.)으로 연결 고정하고 부가중합형 실리콘 인상재(Honigum mono; DMG, Hamburg, Germany)로 매식체 수준 인 상을 채득해 석고 모형을 제작하고 양손조작법[7]으로 중심위 악간관계를 채득하였다. 교합기(PROTARevo5B; KaVo Dental $\mathrm{GmbH}$, Biberach, Germany)에 부착된 모형 상에서 1차 고정 성 임플란트 임시 보철물을 제작하였다.

임시 보철물을 구강 내 장착하는 과정에서 상하악 우측 구치 부의 교합 접촉을 이용해 수직교합고경을 유지하였으며, 교합 조정을 통해 환자에게 편한 적응된 중심위로 재조정하였다. 임 시 보철물의 교합 양식은 상호 보호 교합으로 설정하여 전방유 도 시 구치부 이개 및 절치에 의한 유도를 확인하였다. 3 개월간 경과 관찰한 뒤 하악 우측 구치를 발거하고 즉시 임플란트(TS $\mathrm{III}$ 를 매식하였으며, 상악 구치부의 기존 보철물을 제거하고 교 합평면에 조화되도록 임시 보철물을 수복하였다(Fig. 3). 이 기 간 동안 하악 좌측의 임시 보철물의 파절이 빈번히 발생하여 하 악 좌측 구치부를 먼저 금속-도재를 이용한 최종 보철물로 수복
하였다(Fig. 3C). 2개월 후에 하악 우측 구치부에 임시 보철물을 장착하여 정상적인 중심교합접촉을 허용하는 상호보호교합을 형성하였다.

1 차 임시 보철물에 의해 확정된 치아의 위치를 이용해 임플란 트 모형 상에서 상악 전치부에 맞춤형 지대주(Customfit abutment; Osstem)를 제작하고(Fig. 4) 임시 보철물상에서 구강 내 묘기침을 사용하여 중심위를 채득하였다(Fig. 5). 모형상에서 1 차 임시 보철물의 설면과 교합면을 복제하여 치관 형태의 2차 임시 보철물을 제작하였다. 2 차 임시 보철물은 상악 전치부의 심미성을 높이기 위해 중심선, 미소선과 조화되고, 상순의 길이 와 순측 지지를 고려하여 2회 정도 수정 보완하였다. 이 과정에 서 환자는 교합기에서 $35^{\circ}-40^{\circ}$ 로 설정한 전방유도에 대해 발음 과 저작에 대한 불편감을 호소하였다. 정출된 하악 전치부의 법 랑질 삭제도 불가능하여 전방유도와 심미성을 절충하여 상악 중절치의 절단연의 위치와 설면의 형태를 설정하였다. 이후 4 개 월간 환자와의 충분한 대화를 통해, 환자의 적응도와 심미성, 기능 을 평가하여 최종적인 형태의 임시 보철물을 획득하였다(Fig. O).

\section{최종 보철물의 수복}

상악에서 4 개의 잔존 지대치와 6 개의 임플란트에 대한 최종 인상(Honigum light body, regular body; DMG)을 채득하였다. 


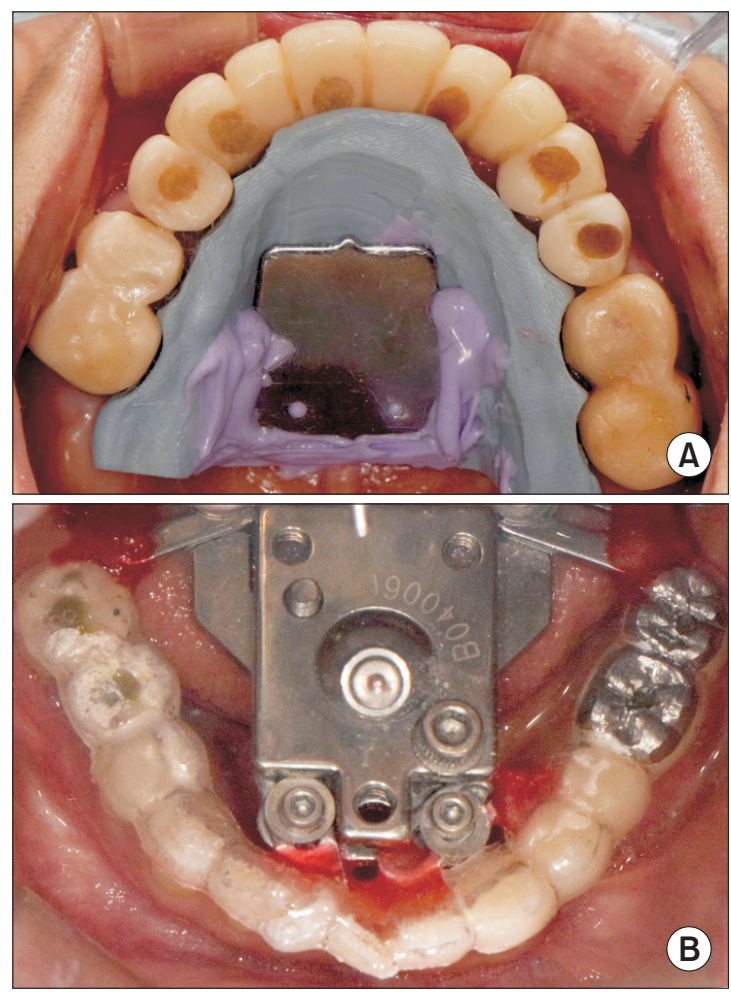

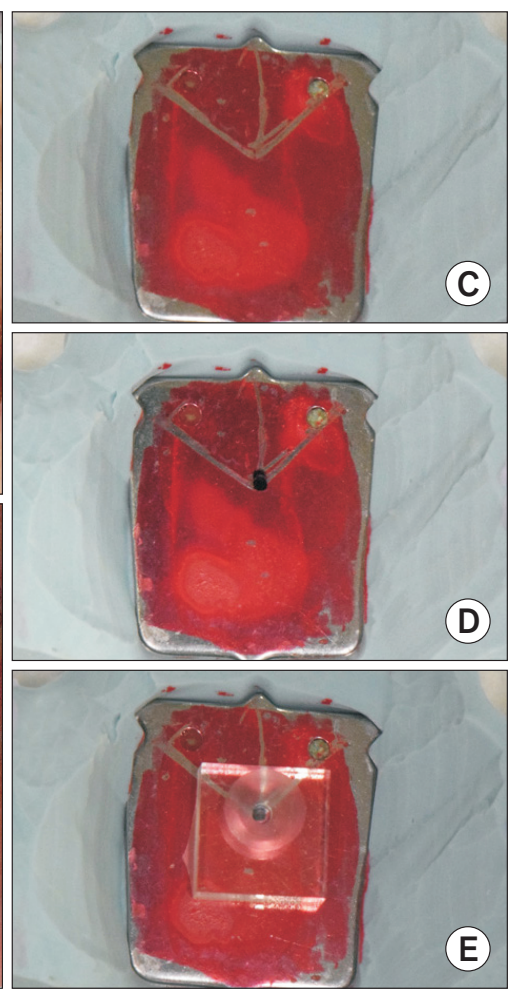

(E)
Fig. 5. Centric relation (CR) registration with gothic arch tracer. (A) Maxillary occlusal view. (B) Mandibular occlusal view. (C) Gothic arch tracing was performed. (D) $1 \mathrm{~mm}$ anterior to CR was marked with black ink. (E) CR position was registered.
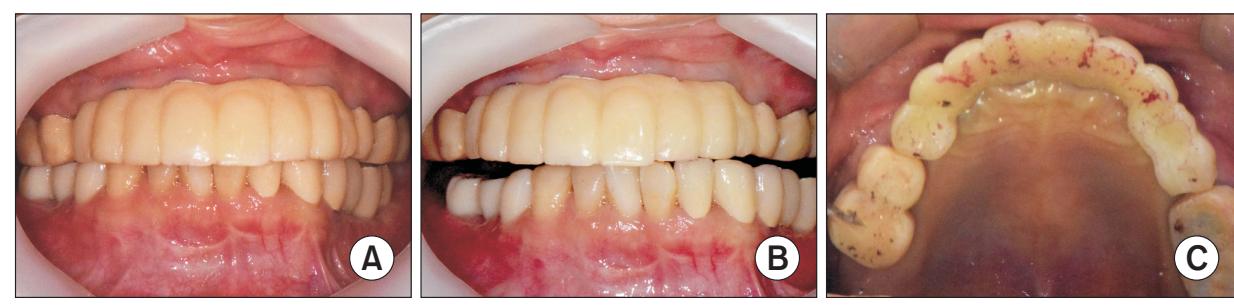

Fig. 6. Second provisional implantsupported fixed prosthesis made on custom abutments. (A) Frontal view on maximum intercuspal position. (B) Frontal view on protrusion. (C) Maxillary occlusal view. Anterior and lateral guidance was established.
임플란트는 매식체 수준으로 인상 채득하였다. 최종 모형에 맞 춤형 지대주 및 임시 보철물을 장착한 뒤 안궁(Artex facebow; Amann Girrbach, Koblach, Austria) 이전하여 반조절성 교합 기(Artex CR articulator; Amann Girrbach)에 부착하였다(Fig. 7A). 상하 주모형을 transfer jig에 부착하고 임플란트 아날로그 에는 지대주를 체결하였다. 금속 지대주에 스캔용 이산화티타 늄 분말(Ceramill scanmaker; Amann Girrbach)을 도포한 뒤 기공용 스캐너(Ceramill Map400; Amann Girrbach)로 디지털 인상을 채득하였다(Fig. 7B). 다음으로 임시보철물을 장착하여 두번째 스캔하였다(Fig. 7C). 획득한 두 stereolithography 파일 을 소프트웨어(Ceramill mind; Amann Girrbach)상에서 중첩 하여 최종 보철물의 형태를 결정하고 상호보호교합을 구성하였 다(Fig. 7D). 이때 design parameter는 치관 변연 상방 $1 \mathrm{~mm}$ 에 $60 \mu \mathrm{m}$ 의 cement gap을 부여하고 변연부의 두께는 $1 \mathrm{~mm}, 65^{\circ}$ offset angle로 하였다. 최종 보철물은 구치부의 경우 단일 구조
지르코니아 블록(Ceramill Zolid FX; Amann Girrbach)을 사 용하였다. 디자인된 지르코니아 보철물은 5축밀링기(Ceramill Motion 2; Amann Girrbach)에서 0.25-, 0.3-, 0.6-, 및 1.0$\mathrm{mm}$ radius drill을 이용하여 가공하였다. 도재 소성로(Ceramill Therm; Amann Girrbach)에서 2시간 동안 $1,450^{\circ} \mathrm{C}$ 로 소성 후 9시간 냉각하였다. 그 후 제조자의 지시에 따라 연마 완성하 였다. 전치부에서는 지르코니아 하부구조(Ceramill Zolid FX) 를 제작하고(Fig. 7E) 비니어 도재(IPS e.max ceram; Ivoclar Vivadent, Schaan, Liechtenstein)를 축성하여 심미성을 보완 하였으며, 연조직부에 치은 색조 도재(Cercon pink; Degudent, Hanau, Germany)를 추가하였다(Fig. 8). 완성된 최종 보철물을 구강 내 시적 시 임시 보철물상에서 형성한 전방 및 측방 유도가 재현됨을 확인할 수 있었다(Fig. 9). 최종 보철물 장착 후 환자는 저작기능과 심미에 대해 만족하였으며 측두하악관절의 증상은 발견되지 않았다(Fig. 10). 

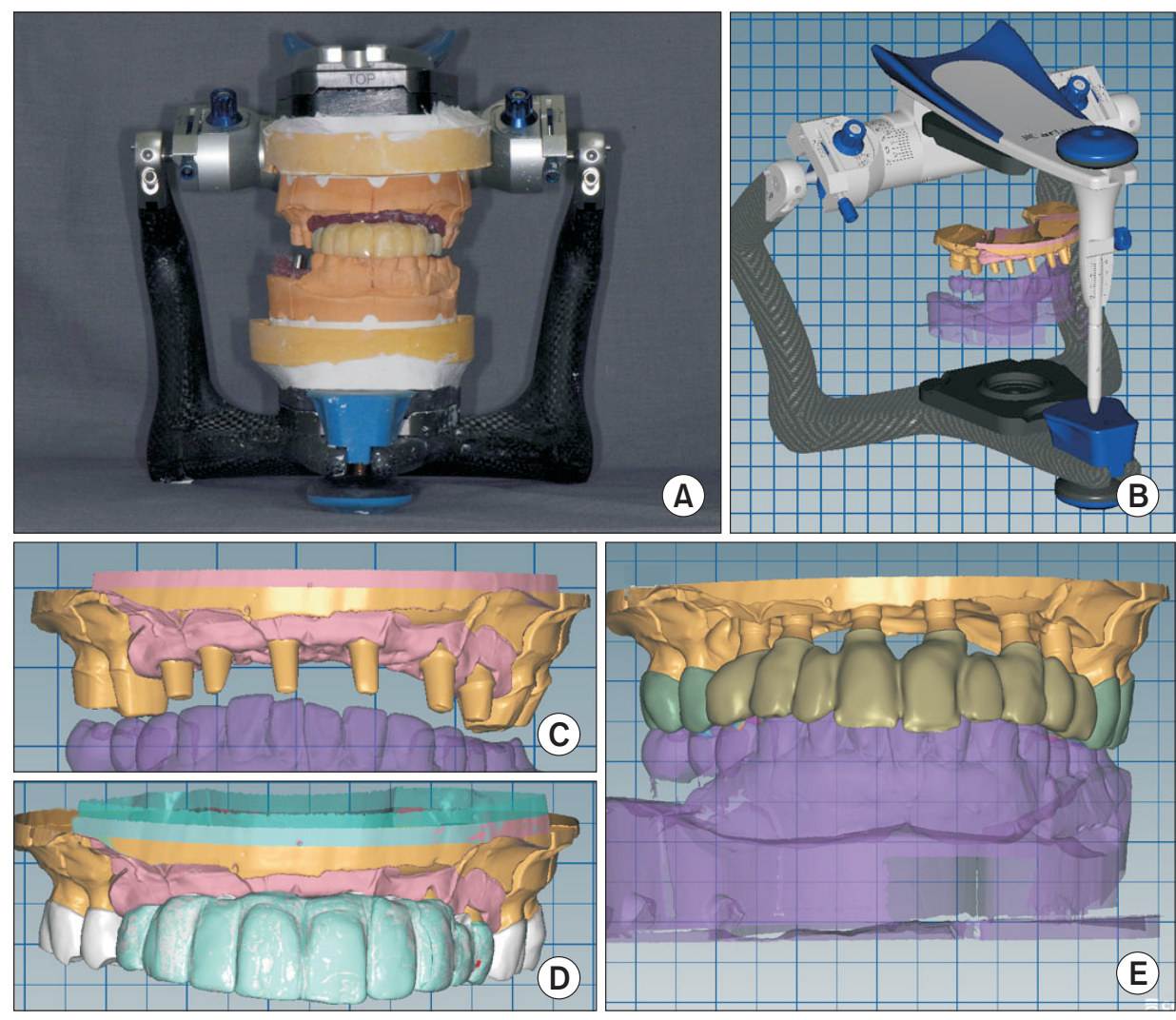

(E)

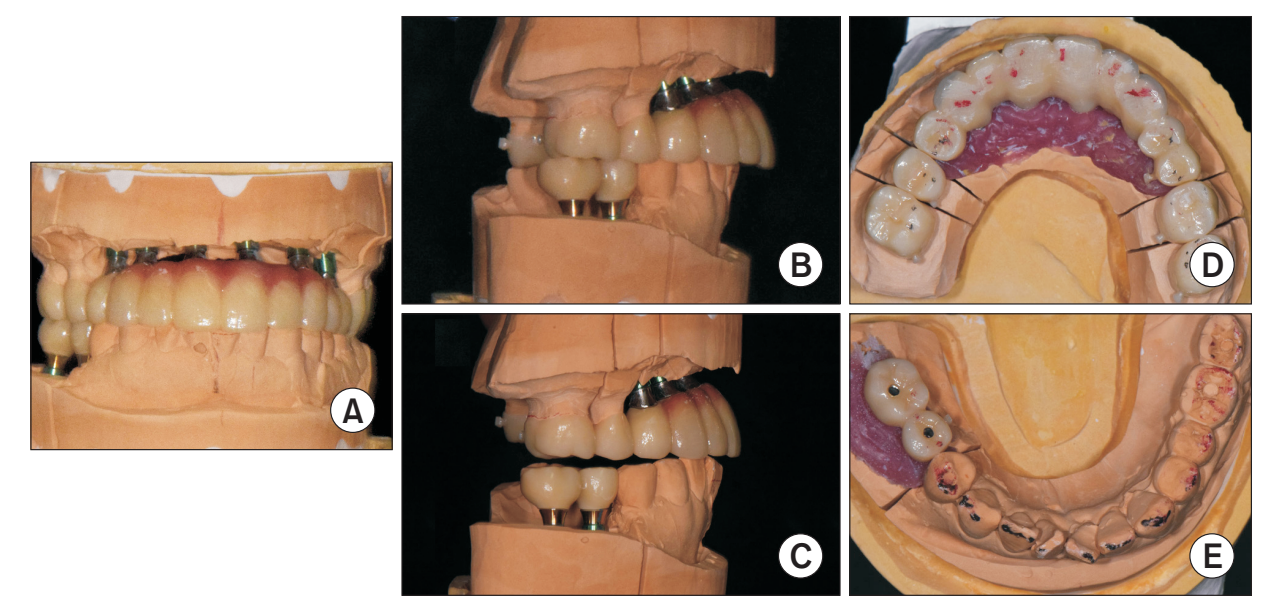

Fig. 7. Designing definitive prosthesis by double-scan method. (A) Models are mounted on Artex articulator by facebow transfer. (B) 3D-scanned data of models were transferred and mounted on virtual Artex articulator with Benette angle: $10^{\circ}$ (both) Immediate side shift: $0 \mathrm{~mm}$ (both) Condylar guidance angle: $35^{\circ}$ (both). (C) Scanned $3 \mathrm{D}$ data of customized abutments and natural abutment. (D) Superimposing scan data of provisional prosthesis and master model. (E) Cutback of anterior segment for porcelain veneer.

\section{고 찰}

환자는 외상으로 인해 상악 6전치와 제1소구치 및 하악 좌 측 구치부가 10대에 상실된 상태로 20년 이상 우측으로만 저작 을 했다고 한다. 이에 따라 턱관절 방사선 사진상에서 우측 작업 측 과두는 부하가 감소되어 정상적인 형태로 남아있고 좌측 비 작업측 과두는 중앙 및 외측 $1 / 3$ 에 비교적 큰 부하가 작용해 관 절원판의 중앙과 외측이 얇아지거나 과두의 중앙과 외측 $1 / 3$ 에 형태변화(deviation in form)가 나타났다[9]. Dawson [10]은 악관절 병변이 예전에 이미 발생하였고, 관절면에 순응적 변화 가 일어난 경우 악관절의 구조는 변형되었으나 불편함 없이 부 하를 받아들일 수 있으므로 적응된 중심위에서 최대교두감합을 형성하도록 권고하였다. 본 환자는 임시치아 수복 단계에서 중 심위 악간관계를 채득하여 임시 수복물을 제작하였다. 장착 시 중심위 악간관계를 확립하려고 시도했으나, 불편감을 호소하 여 다시 적응된 중심위로 수정하였다. 임시 수복물을 장착한 6 

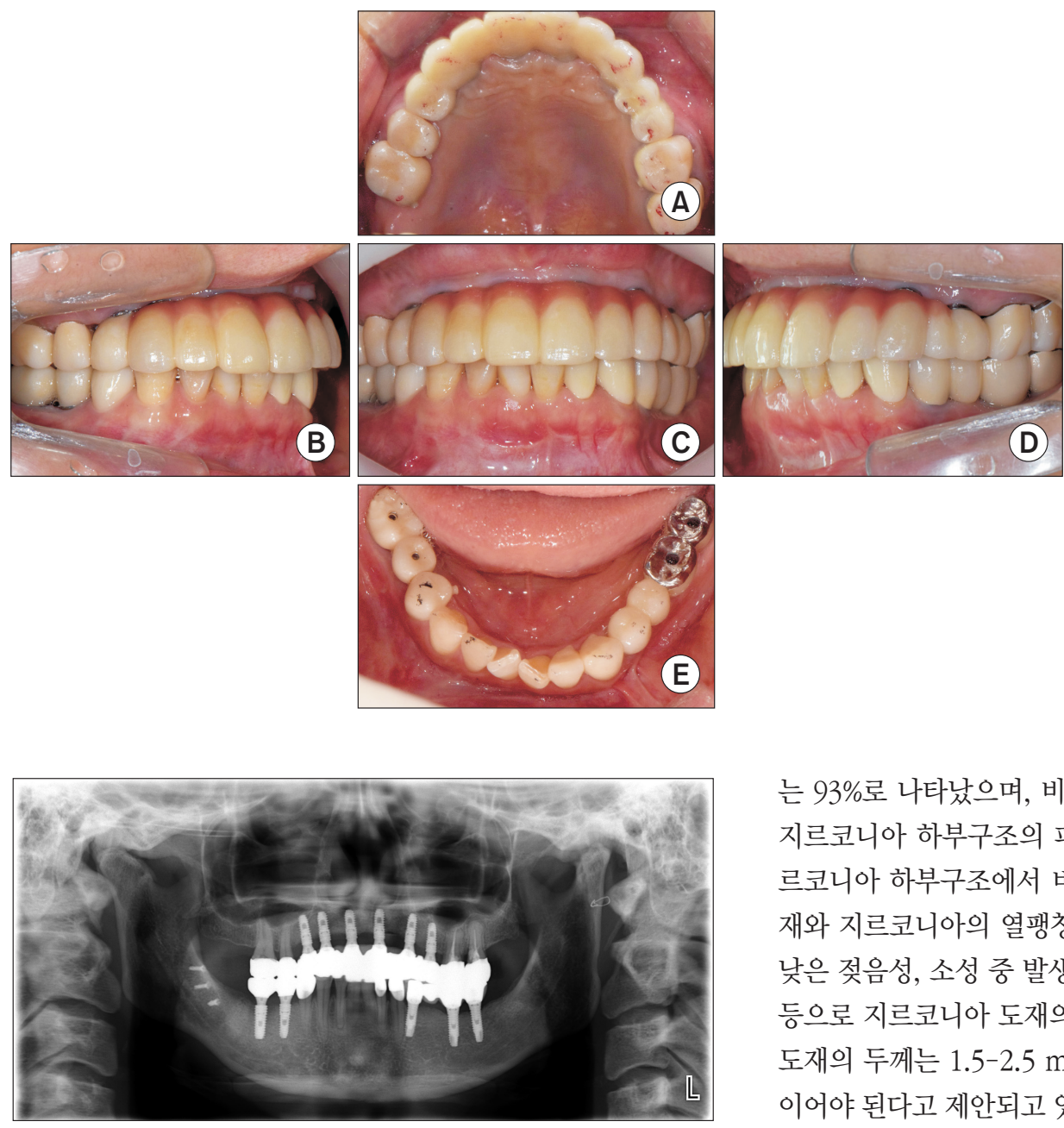

Fig. 10. Postoperative panoramic view.

개월 이상의 기간 동안 환자는 악관절이 안정되고 반복재현성 이 있는 적응된 중심위를 가지고 있음을 보여주었다. 다만 최종 수복물을 장착하기 전에 중심위로 교합기에 재부착하여 중심 위-최대교두간접촉위 사이의 거리(centric relation-maximum intercuspal position discrepancy)를 조정하였다. 최종 수복 후 현재까지 6개월이 넘는 기간에 환자는 좌우측을 모두 사용할 수 있고 특히 좌측 저작이 더 편안하다고 하였다.

환자는 심미성에 관심이 높아 지르코니아 수복물을 선택하 였고 구치부에서도 잔존 지대치에 단일 구조 지르코니아관으로 단일치 수복하였다. 전치부에서는 설면과 절단연에 임시치아의 전방유도가 그대로 재현된 $\mathrm{CAD}-\mathrm{CAM}$ 지르코니아 하부구조를 제작하고 순면에만 열팽창계수가 지르코니아와 유사한 비니어 도재로 축성하여 비니어 도재의 파절 가능성을 감소시키도록 노력하였다.

Sailer 등[11]에 따르면 임플란트 지지 금속-도재 고정성 국소 의치는 5년 생존율이 $98.7 \%$, 지르코니아-도재 고정성 국소의치
Fig. 9. Definitive dental prosthesis after placement. (A) Maxillary occlusal view. (B) Right lateral view. (C) Frontal view. (D) Left lateral view. (E) Mandibular occlusal view.
는 93\%로 나타났으며, 비니어 도재의 미세파절(chipping)이나 지르코니아 하부구조의 파절이 실패의 원인으로 나타났다. 지 르코니아 하부구조에서 비니어도재가 파절되는 원인은 장석도 재와 지르코니아의 열팽창계수의 차이, 장석 도재 내의 기포와 낮은 젖음성, 소성 중 발생하는 도재의 수축, 소성 후 빠른 냉각 등으로 지르코니아 도재의 두께는 최소한 0.5-0.7 mm, 비니어 도재의 두께는 1.5-2.5 mm, 연결부의 두께는 9-16 mm $\mathrm{mm}^{3}$ 이상 이어야 된다고 제안되고 있다[12].

지르코니아를 이용한 보철물은 생체친화성이 높고 세균부착 이 어려우며 상전이 강화 현상으로 강도가 높고 심미성이 뛰어 난 장점이 있다. 이는 $\mathrm{CAD}-\mathrm{CAM}$ 방식을 이용하여 데이터의 획 득, 조정, 보관이 간편한 장점이 있다. 최근에는 스캐너의 정확 도(accuracy)가 높아지면서 변연이나 내면적합도가 기존의 보 철물과 유사한 정도가 되었고, 제작이 간편해 시간과 노력, 비 용이 절감되고 있다[7,8]. 본 증례에서는 이를 고려해 상악 전치 부 보철물의 설면과 순면의 형태를 두 차례에 걸친 임시 수복물 을 장착하여 충분히 환자의 구강 내에 적합한 보철물을 제작하 고자 하였으며 이에 따라 장착 후 최소한의 수정으로 지르코니 아 하부구조의 설면에서 약화되는 현상을 막으려고 노력하였 다. 본 증례의 구치부는 단일 구조 지르코니아관으로 단일치 수 복하였다. Hamza와 Sherif [13]는 여러 가지 CAD-CAM 시스템 에 관한 비교연구에서 본 증례와 같이 Ceramill Zolid block을 사용해서 Ceramill Motion 2 밀링기로 가공한 다음 소성해 제 작한 지르코니아관의 mean vertical marginal discrepancy가 $25.1 \pm 8.2 \mu \mathrm{m}$ 이었다고 보고한 바 있어 지르코니아관의 정확도 
는 이제 상당히 만족스러운 것으로 평가되고 있다.

본 증례는 적응된 중심위를 가진 환자에서 다수의 임플란트 를 매식하고 잔존 자연치와 함께 전악수복을 시행하여 기능 및 심미적으로 우수한 결과를 얻었다. 보철물 장착 후 6 개월간 유 지 관리나 악관절의 이상 증상 없이 잘 적응하여 안정된 교합과 구강위생관리가 이루어지고 있다.

\section{ACKNOWLEDGEMENTS}

This paper was supported by Wonkwang University in 2019.

\section{CONFLICTS OF INTEREST}

The authors declare that they have no competing interests.

\section{ORCID}

Jeong-Hye An

https://orcid.org/0000-0003-3425-1601

Ji-Hye Jung

https://orcid.org/0000-0003-3322-4011

Hye-Won Cho

https://orcid.org/0000-0003-0623-5647

\section{REFERENCES}

1. Venezia P, Torsello F, Cavalcanti R, D'Amato S. Retrospective analysis of 26 complete-arch implant-supported monolithic zirconia prostheses with feldspathic porcelain veneering limited to the facial surface. J Prosthet Dent 2015;114:506-512. doi: 10.1016/j.prosdent.2015.02.010.

2. Mericske-Stern RD, Taylor TD, Belser U. Management of the edentulous patient. Clin Oral Implants Res 2000;11 Suppl 1:108-125.

3. Rojas-Vizcaya F. Full zirconia fixed detachable implant- retained restorations manufactured from monolithic zirconia: clinical report after two years in service. J Prosthodont 2011;20:570-576. doi: 10.1111/j.1532-849X.2011.00784.x.

4. Papaspyridakos P, Lal K. Computer-assisted design/ computer-assisted manufacturing zirconia implant fixed complete prostheses: clinical results and technical complications up to 4 years of function. Clin Oral Implants Res 2013;24:659-665. doi: 10.1111/j.1600-0501.2012.02447.x.

5. Hobo S, Iwata T. Reproducibility of mandibular centricity in three dimensions. J Prosthet Dent 1985;53:649-654. doi: 10.1016/0022-3913(85)90013-7.

6. Jiménez-Silva A, Tobar-Reyes J, Vivanco-Coke S, PasténCastro E, Palomino-Montenegro H. Centric relationintercuspal position discrepancy and its relationship with temporomandibular disorders. a systematic review. Acta Odontol Scand 2017;75:463-474. doi: 10.1080/00016357.2017.1340667.

7. Mangano FG, Veronesi G, Hauschild U, Mijiritsky E, Mangano C. Trueness and precision of four intraoral scanners in oral implantology: a comparative in vitro study. PLoS One 2016;11:e0163107. doi: 10.1371/journal.pone.0163107.

8. Imburgia M, Logozzo S, Hauschild U, Veronesi G, Mangano C, Mangano FG. Accuracy of four intraoral scanners in oral implantology: a comparative in vitro study. BMC Oral Health 2017;17:92. doi: 10.1186/s12903-017-0383-4.

9. Solberg WK, Hansson TL, Nordström B. The temporomandibular joint in young adults at autopsy: a morphologic classification and evaluation. J Oral Rehabil 1985;12:303321. doi: 10.1111/j.1365-2842.1985.tb01285.x.

10. Dawson PE. Functional occlusion: from TMJ to smile design. Saint Louis: Mosby Elsevier; 2007;xiii-630.

11. Sailer I, Strasding M, Valente NA, Zwahlen M, Liu S, Pjetursson BE. A systematic review of the survival and complication rates of zirconia-ceramic and metal-ceramic multiple-unit fixed dental prostheses. Clin Oral Implants Res 2018;29 Suppl 16:184-198. doi: 10.1111/clr.13277.

12. Raigrodski AJ, Hillstead MB, Meng GK, Chung KH. Survival and complications of zirconia-based fixed dental prostheses: a systematic review. J Prosthet Dent 2012;107:170177. doi: 10.1016/S0022-3913(12)60051-1.

13. Hamza TA, Sherif RM. In vitro evaluation of marginal discrepancy of monolithic zirconia restorations fabricated with different CAD-CAM systems. J Prosthet Dent 2017;117:762-766. doi: 10.1016/j.prosdent.2016.09.011. 